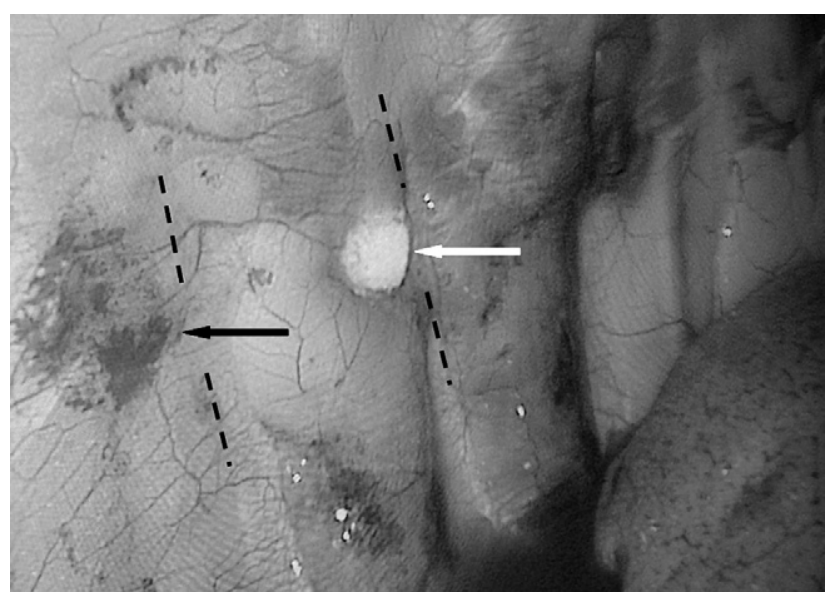

FIGURE 2. Thoracoscopic image demonstrating formation of ice ball in the affected intercostal space (white arrow) above the paravertebral sulcus (obscured by overlying lung). A previous site of cyroprobe application in the intercostal space below can be seen (black arrow). The black dashed lines represent the lower margins of the 11th and 12th ribs.

The thoracoscopic technique uses readily available instruments and allows for the safest approach, placement, and application of the cyroprobe under direct vision. It avoids repeat intercostal nerve blocks and epidurals and avoids the potential for pneumothorax that is inherent from "blind" percutaneous approaches. We have used separate punctures and direct placement of the cyroprobe into the intercostal spaces affected rather than placing the probe through the port so as to preserve pleura, "focus" the iceball's effect, and maintain accuracy of localization. It would not be unrea- sonable to adapt the technique and attempt a transpleural application of the probe through a single port, thereby avoiding separate stab incisions over the intercostal spaces affected, although for the reasons mentioned the cyroanlagesic effect may be reduced. The position of the anterolateral $10-\mathrm{mm}$ port in the seventh intercostal space allows simple retraction of the lung medially and excellent views of the paravertebral area. The need for decortication in postthoracotomy patients with intercostal neuralgia may add some difficulty to an otherwise simple procedure, but additional port placements and careful adhesiolysis does not preclude this approach.

In summary, this single-port minimally invasive technique allows multiple safe, precise, and direct applications of the cyroprobe to the areas affected and eliminates the need for further repetitive intercostal nerve blocks, epidurals, and the need for long-term medication.

\section{References}

1. Maiwand MO, Makey AR, Rees A. Cryoanalgesia after thoracotomy: improvement of technique and review of 600 cases. J Thorac Cardiovasc Surg. 1986;92:291-5.

2. Pastor J, Morales P, Cases E, Cordero P, Piqueras A, Galán G, et al. Evaluation of intercostal cryoanalgesia versus conventional analgesia in posthoracotomy pain. Respiration. 1996;63:241-5

3. Detterbeck FC. Efficacy of methods of intercostal nerve blockade for pain relief after thoracotomy. Ann Thorac Surg. 2005;80:1550-9.

4. Moorjani N, Zhao F, Tian Y, Liang C, Kaluba J, Maiwand MO. Effects of cryoanalgesia on post-thoracotomy pain and on the structure of intercostal nerves: a human prospective randomized trial and a histological study. Eur J Cardiothorac Surg. 2001;20:502-7.

5. Byas-Smith MG, Gulati A. Ultrasound-guided intercostal nerve cryoablation. Anesth Analg. 2006;103:1033-5.

\title{
The Sorin Freedom SOLO stentless aortic valve: Technique of implantation and operative results in 109 patients
}

\author{
Thierry Aymard, MD, Friedrich Eckstein, MD, Lars Englberger, MD, Mario Stalder, MD, \\ Alexander Kadner, MD, and Thierry Carrel, MD, Berne, Switzerland
}

Aortic valve replacement with a biological prosthesis is nowadays increasingly performed inasmuch as tissue valves

\footnotetext{
From the Department of Cardiovascular Surgery, Swiss Cardiovascular Center, University Hospital Berne, Switzerland.

Disclosures: None.

Received for publication Nov 28, 2008; revisions received Dec 26, 2008; accepted for publication Jan 19, 2009; available ahead of print Oct 9, 2009.

Address for reprints: Thierry Carrel, MD, Department of Cardiovascular Surgery, University Hospital Berne, CH-3010 Berne, Switzerland (E-mail: thierry.carrel@ insel.ch).

J Thorac Cardiovasc Surg 2010;139:775-7

$0022-5223 / \$ 36.00$

Copyright (c) 2010 by The American Association for Thoracic Surgery

doi:10.1016/j.jtcvs.2009.01.011
}

have improved regarding hemodynamic performance and durability, although they leave younger patients $(<60-65$ years) at risk for reintervention. ${ }^{1}$ The first generation of stentless valves usually required two suture lines at the annulus level and above. The second generation includes adaptation of the outside profile of the framework to simplify technique of implantation. Whether this change in design will crucially improve the long-term performance is currently unknown.

We summarize the technique of implantation and the early performance of a consecutive series of 109 patients who received a Sorin Freedom SOLO stenteless tissue valve (Sorin Biomedica Spa, Saluggio, Italy). 
TABLE 1. Main patient characteristics

\begin{tabular}{lc}
\hline Mean age (y) & $72 \pm 9$ \\
Male gender, $\mathrm{n}(\%)$ & $63(58 \%)$ \\
Isolated aortic valve disease & $46(42 \%)$ \\
Additional operation & $63(58 \%)$ \\
$\quad$ CABG & 38 \\
$\quad$ Aortic surgery & 9 \\
$\quad$ Other cardiac surgery & 16 \\
Median EuroSCORE & $7(3-20)$ \\
Prior cardiac surgery & $11(10 \%)$ \\
Mean preop NYHA class & $2.5 \pm 1.07$ \\
Mean LVEF (\%) & $55 \pm 12$ \\
Preop peak-to-peak gradient (mm Hg) & $80 \pm 35$ \\
Mean gradient (mm Hg) & $56 \pm 21$ \\
Mean crossclamp time (min) & $42(29-80)$ \\
Median ICU time (d) & $1(0.5-4)$ \\
Median total hospitalization (d) & $8(6-11)$ \\
Postop peak-to-peak gradient (mm Hg) & $16 \pm 7$ \\
Postp mean gradient (mm Hg) & $8 \pm 4.8$ \\
Trivial central aortic regurgitation & $10(9 \%)$ \\
Mean postoperative NYHA class & $1.1 \pm 0.5$ \\
\hline
\end{tabular}

$C A B G$, Coronary artery bypass grafting; $N Y H A$, New York Heart Association; $L V E F$, left ventricular ejection fraction; $I C U$, intensive care unit.

\section{PATIENTS AND METHODS}

A consecutive series of 109 patients who underwent elective aortic valve replacement with a Sorin Freedom SOLO stentless valve (Sorin Biomedica, Saluggia, Italy) between January 2005 and June 2007 was evaluated prospectively. The demographic characteristics are summarized in Table 1. Outcome analysis was approved by the local ethics committee and informed consent was obtained from each patient. Follow-up data were collected during the early postoperative course (ie, 30 days). Thereafter, patients were followed up at regular intervals within a specialized outpatient clinic.

\section{DEVICE DESCRIPTION AND IMPLANTATION TECHNIQUE}

The Freedom Sorin SOLO stentless tissue valve is constructed from two bovine pericardial sheets without fabric re- inforcement (Figure 1). The detoxification process is directed by homocysteic acid and the valve is stored in a sterile neutral aldehyde-free solution. Rinsing is not necessary before implantation. This valve differs from the previous generation because the outside pericardial support has been eliminated and the design follows the natural shape of the ring and commissures. This allows a simplified technique of implantation in a strictly supra-annular position with a single suture line.

A transverse aortotomy is performed approximatively $1 \mathrm{~cm}$ above the presumed level of the commissures of the native aortic valve. Supra-annular calcifications of the aortic root are considered as contraindications for the implantation of the SOLO valve. The size of the sinotubular junction should not exceed the annulus diameter by more than 2 to $3 \mathrm{~mm}$; otherwise, insufficient leaflet coaptation may occur. The implantation starts with three $4-0$ polypropylene sutures placed in a supra-annular position at the midpoint of each sinus and then passed through the external pericardial flange of the SOLO valve. The valve is then parachuted into the aortic root and tied. Thereafter, these sutures run continuously $2 \mathrm{~mm}$ above the annulus. At the level of the commissures, each suture is passed out of the aorta and tied with the suture coming from the adjacent sinus. An intraoperative view is shown in Figure 2.

Postoperative anticoagulation includes $100 \mathrm{mg}$ salicylic acid from postoperative day 1 and subcutaneous low-weight heparin until discharge.

\section{RESULTS}

Median size of implanted valves was $25 \mathrm{~mm}$, ranging from 19 to $27 \mathrm{~mm}$. The exact distribution was $19 \mathrm{~mm}$ in 2 cases, $21 \mathrm{~mm}$ in 18 cases, $23 \mathrm{~mm}$ in 28 cases, $25 \mathrm{~mm}$ in 32 cases, and $27 \mathrm{~mm}$ in 29 cases.

Two (1.8\%) patients died during the first 30 days: one patient from a major neurologic event and another from sudden death. Re-exploration for bleeding was necessary in 5 (4.5\%)
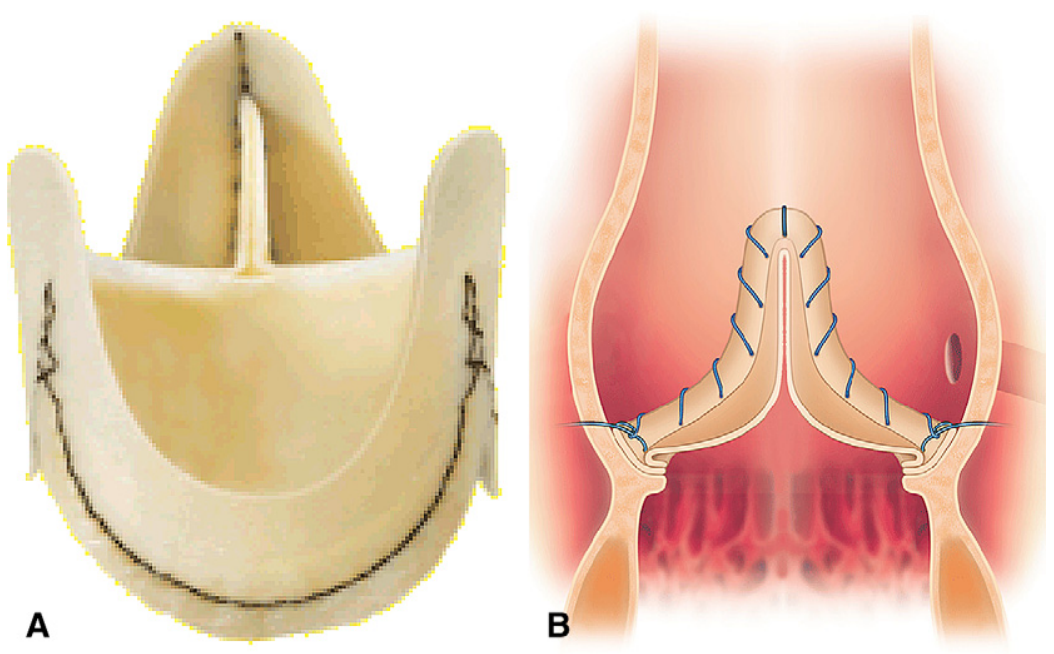

FIGURE 1. A, The SOLO stentless aortic tissue valve. B, Technique of implantation: a running supra-annular suture line. 


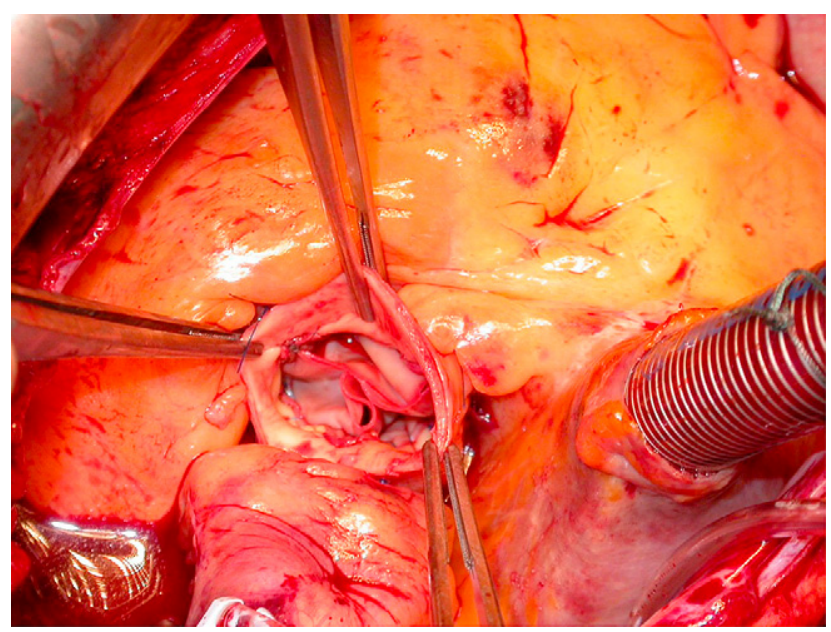

FIGURE 2. Intraoperative view with some excessive leaflet tissue assuming excellent coaptation.

patients. Postoperative hemodynamic performance was excellent (Table 1). Two (1.8\%) patients required permanent pacemaker implantation before discharge. Within a complete follow-up period extending up to 48 months, 2 patients underwent replacement of the valve because of regurgitation.

\section{DISCUSSION}

This is a prospective registry of the first 109 patients who received the new Sorin Freedom SOLO aortic tissue valve. Simpler technique of implantation was appreciated by all surgeons, and after a short learning curve it was found to be easier to implant than any other stentless valve.

One of the main goals of stentless valves is to improve hemodynamic performance. The elimination of the rigid ring allows some reduction in the transvalvular gradient and may lead to a more complete regression of the left ventricular mass and improved long-term survival. However randomized studies comparing stentless and stented valves show conflicting results. ${ }^{2-4}$

A substantial proportion of surgeons probably consider the implantation of a stentless valve more demanding than that of a stented valve, with longer perfusion and crossclamping times, and are reluctant to introduce stentless valves in their repertoire.

The new Sorin SOLO valve is considerably easier and faster to implant. The design is close to the structure of the native valve, and the strictly supra-annular implantation provides a greater effective orifice area index for a given valve size.

We confirmed the excellent hemodynamic performance ${ }^{5}$ and were able to implant larger sizes when compared with stented bioprostheses. The strictly supra-annular position seems to reduce the rate of postoperative complete atrioventricular block, which was only $1.8 \%$ in this series.

\section{References}

1. Ruel M, Chan V, Bédard P, Kulik A, Ressler L, Lam BK, et al. Very long-term survival implications of heart valve replacement with tissue versus mechanical prostheses in adults $<60$ years of age. Circulation. 2007;116(11 Suppl):I294-300.

2. Kunadian B, Vijayalakshmi K, Thornley AR, de Belder MA, Hunter S, Kendall S, et al. Meta-analysis of valve hemodynamics and left ventricular mass regression for stentless versus stented aortic valves. Ann Thorac Surg. 2007;84:73-8.

3. Ali A, Halstead JC, Cafferty F, Sharples L, Rose F, Coulden R, et al. Are stentless valves superior to modern stented valves? a prospective randomized trial. Circulation. 2006;114(1 Suppl):I535-40.

4. Perez de Arenaza D, Lees B, Flather M, Nugara F, Husebye T, Jasinski M, et al Randomized comparison of stentless versus stented valves for aortic stenosis: effects on left ventricular mass. Circulation. 2005;112:2696-702.

5. Da Col U, Di Bella I, Bardelli G, Ramoni E, Affronti A, Vidili A, et al. Short-term hemodynamic performance of the Sorin Freedom SOLO stentless valve. J Heart Valve Dis. 2007;16:546-50.

\title{
Intraoperative recognition of an intracavitary left anterior descending coronary artery
}

\author{
Lucas H. A. Sanders, MD, FCS(SA), FRACS, ${ }^{\mathrm{a}, \mathrm{b}}$ Mohamed A. Soliman Hamad, MD, ${ }^{\mathrm{a}}$ \\ Mark A. J. Newman, FRACS, MD, ${ }^{b}$ and Bart H. van Straten, MD, ${ }^{a}$ Eindhoven, The Netherlands, and Perth, \\ Australia
}

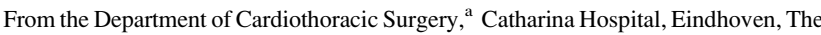
Netherlands; and Department of Cardiothoracic Surgery, ${ }^{\mathrm{b}}$ Sir Charles Gairdner Hospital, Nedlands, Perth, Australia.

Disclosures: None.

Received for publication Jan 28, 2009; accepted for publication Jan 31, 2009; available ahead of print April 9, 2009.

Address for reprints: Lucas H. A. Sanders, MD, FCS(SA), FRACS, Department of Cardiothoracic Surgery, Sir Charles Gairdner Hospital, Hospital Ave, Nedlands,

Australia (E-mail: lucmedi@hotmail.com).

J Thorac Cardiovasc Surg 2010;139:777-8

$0022-5223 / \$ 36.00$

Copyright (c) 2010 by The American Association for Thoracic Surgery

doi:10.1016/j.jtcvs.2009.01.016
}

An intracavitary left anterior descending (LAD) coronary artery, the extreme form of an intramyocardial coronary artery, is difficult to recognize, even on retrospective review of the coronary angiogram. ${ }^{1}$ The right ventricle usually is entered during explorative dissection. ${ }^{1}$ An intracavitary LAD typically enters the right ventricle early in its descending course (possibly with an acute angle) and emerges to the surface subtly in a long curve. With an acute change of depth course, one may suspect an intracavitary or intramyocardial location. ${ }^{1,2}$ Preoperatively, an intramyocardial coronary 